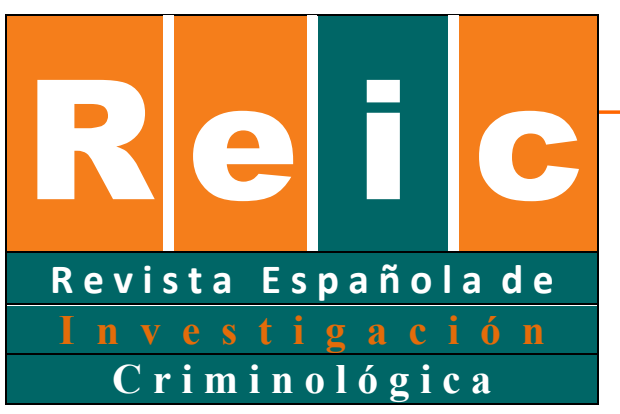

Gómez-Bellvís \& Miró

\title{
Do or do not, there is no "try": An exploratory quasi- experimental study of intuitions of justice applied to attempt and completion of the crime of homicide.
}

\section{Hazlo o no lo hagas, no lo intentes: Un estudio exploratorio cuasiexperimental sobre las intuiciones de justicia aplicadas a la tentativa y a la consumación del delito de homicidio.}

Ana Belén Gómez-Bellvís ${ }^{1}$

CRÍMINA. Centro para el estudio y prevención de la delincuencia.

Fernando Miró Llinares (D)

Universidad Miguel Hernández de Elche

\begin{abstract}
An emerging debate in criminal law concerns whether the penal system should integrate the community's intuitions of justice. Using a sample of 659 participants, this study aims to analyse different intuitions of justice related to different stages of attempts and completion of homicide as well as to evaluate whether legal training modifies these intuitions. The results suggest that participants grade differently both criminal liability and formal sanction associated with different scenarios and that specialized legal knowledge has no relevance to the intuitive distribution of these variables. We conclude by analysing some of the implications of these results for the development of criminal legislative policy.
\end{abstract}

Keywords: intuitions of justice, attempt, completion, empirical methodologies, quasiexperimental designs.

\footnotetext{
${ }^{1}$ La correspondencia debe dirigirse a: Ana Belén Gómez Bellvís. Centro Crímina para el estudio y la prevención de la delincuencia, Ed. Hélike, Universidad Miguel Hernández, Avda. de la Universidad s/n, Elche 03202, España. Ana.gomezb@umh.es
}

Revista Española de Investigación Criminológica

Artículo 3, Número 17 (2019)

https://doi.org/10.46381/reic.v17i0.227

www.criminologia.net

ISSN: 1696-9219 


\section{RESUMEN}

Uno de los debates emergentes en Derecho penal es sobre si el sistema penal debe integrar las intuiciones de justicia de la comunidad. Con una muestra de 659 participantes, el objetivo de este estudio ha sido, por un lado, analizar diferentes intuiciones de justicia relativas a las distintas tentativas y la consumación de homicidio, así como evaluar si la formación en derecho modula estas intuiciones. Los resultados apuntan a que los participantes gradúan tanto la responsabilidad penal como la sanción formal en diferentes casos escenarios y que los conocimientos especiales en Derecho no tienen relevancia en la distribución intuitiva de estas variables. Concluimos analizando algunas de las implicaciones que tienen estos resultados en la elaboración de la política legislativa penal.

Palabras clave: intuiciones de justicia, tentativa, consumación, metodologías empíricas, diseños cuasiexperimentales.

\section{Is killing just as serious as attempting to kill? "It's up to me."}

In most penal systems, an individual who completes a crime - fully carries out an illegal act and causes the underlying illegal result - is perceived as deserving a more severe punishment than an individual who merely attempts the same crime (Bittner, 2008) because, although the latter has completed the proscribed conduct that could have produced the illicit result, the unlawful result has not been achieved. Thus, in our penal system, an individual who has attempted but not completed a crime deserves a less severe punishment than that given to an individual who has caused the legislatively disparaged result. We could end our discussion here by saying that this is so because it is just; because it should be so; or because it is more appropriate than the alternative on account of deontological and axiological reasons rooted in multiple theoretical constructs on the difference between attempt and completion, ${ }^{2}$ assuming that is irrelevant whether the above justifications are consistent with majority opinion. This article, however, attempts the converse: to open the door wide to the potential relevance of the community's intuitions of justice, which might lead to the revision of penalties by a particular criminal institution, and which we should be able to identify, measure, and reflect upon, not only regarding their relevance and existence, but also regarding the best possible methodology for restraining them. We will do so by focusing

\footnotetext{
${ }^{2}$ See generally the traditional manuals; in the European context, see, Roxin (2014, 2017, pp. 843-854); or Mir Puig (2015) and the Anglo-Saxon, Fletcher (2000).
}

Revista Española de Investigación Criminológica

Artículo 3, Número 17 (2019)

https://doi.org/10.46381/reic.v17i0.227

www.criminologia.net

ISSN: 1696-9219 
exclusively on the aforementioned difference between the deserved punishments for attempted and completed crimes - on which the majority of the doctrine agrees - as a first, uncontroversial step that will nevertheless open the door to whether - and how and why we can and should measure society's opinions about penal institutions and their consequences.

As we have set forth, the basis for differentiating, in terms of the deserved punishment, between a completed crime and an attempted crime has been widely discussed by philosophers (Donnelly-Lazarov, 2015) as well as criminal law scholars (among others, Mañalich, 2004; Roxin, 2017) and constitutes a classic topic of discussion among objectivists and subjectivists (Lippke, 2016). Although in most of the doctrine, attempt deserves less punishment than a completed act based on the result produced and in accordance with the danger that the act effectively poses for legal rights (Gil Gil, 2015; Serrano Piedecasas, 1999), taking the interest of other individuals suggests that they should be punished equally because of the actor's intent, which is usually identical in both situations (Christopher, 2004; Deely, 2016). Other authors have advanced mixed theories that "begin with criminal will as the basis for punishment but believe it necessary to limit punishment through objective requirements, such as the act having shocked the community" (Mir Puig, 2015, p. 348).

The fact that the justification for this different deserved punishment between an attempt and a completed crime does not refer explicitly to intuitions of justice or community opinions does not mean that there must not be tacit acceptance of them. After all, as is often declared, and we believe rightly, criminal law in a democratic society should reflect the shared values of those who must respect it and similarly must encompass behaviours that are socially devalued (Mir Puig, 2015). Nevertheless, this notion gives the immediate impression that public opinion is considered irrelevant to the effects of the material legitimation of different deserved punishments and that it is perceived as a problem, rather than as an argument for legitimacy. This is due to the fear that it will lead to populist punitive forms whereby the opinions of the public do not correspond to the values that have traditionally been assigned to criminal law in a social-democratic legal state (Norval Morris, 1974).

Revista Española de Investigación Criminológica

Artículo 3, Número 17 (2019)

https://doi.org/10.46381/reic.v17i0.227

www.criminologia.net

ISSN: 1696-9219 
We should not be afraid, however, to reopen the debate about the real role of the public in the formulation and legitimation of the law (Duus-Otterström, 2018; Miró Llinares, 2017a; Robinson, 2013; Varona, 2016). This is so if we at least accept the notion suggested by Feinberg (1995) that a criminal law that is completely divorced from social sensitivities would be a penal system "in which only an intellectual elite matters, and the genuine convictions of a majority consensus are dismissed as moral superstitions." (p.8). Moreover, considering empirical knowledge about compliance with norms (Miró Llinares, 2017b), a criminal law that is opposed to the community's intuitions of justice cannot fulfil the function of punishment to deter behaviours that are harmful to protected interests, given the intense relationship between perceived legitimacy and individual conduct (Miró Llinares, 2017a; Robinson, 2013).

At a time in which dichotomous fallacies are increasingly common, we must clarify that asserting that certain social consensuses may be relevant to the dialectical process of moral construction to justify the institutions of the penal system - such as attempt itself and the punishment it deserves - does not mean that the decision on that difference in punishment should depend exclusively on a more or less well-structured survey. We are not defending a dull empiricism that rests on the possibility of "testing" the principles and penal institutions by simply checking the existence of determined social consensus. It is obvious that the democratic basis for the intervention of criminal law in a legal state is more complex and goes beyond simply imposing the will of the majority, at least for a Criminal Law that seeks not to fall for relativism. However, that fact does not imply that the (potential) knowledge of reality should be ignored; in particular, the potential existence of a social consensus is related to the ideas of justice that are also held by the same experts who elaborate the moral principles. In fact, even from a constructivist ethical position far removed from empiricism such as Habermas' theory of communicative action (2001) or Nino's epistemological constructivism (1988), the convenience of paying attention to the social practice of moral discourse is recognized - along with the practice itself - as relevant for inferring the rules and factual criteria presupposed in that practice. In fact, ignoring this potential knowledge would mean completely leaving aside the social consensus from the democratic

Revista Española de Investigación Criminológica

Artículo 3, Número 17 (2019)

https://doi.org/10.46381/reic.v17i0.227

www.criminologia.net

ISSN: 1696-9219 
argumentation of criminal intervention, with the risk of falling on a circular metaphysical idealism.

The decision of whether killing and attempting to kill are equally serious crimes can only be made by society through the promulgation of a criminal code. The dogmatic system of Criminal Law must be built upon the principle of proportionality and, in the end, upon an ethical justice basis and the appropriate punishment in both cases. However, only from an idealistic constructivism, believing that to understand a moral truth an individual reflection absolutely isolated and alien to social reality is adequate, would be irrelevant the social consensus knowledge of the arguments on which those are based. Not only is this topic not currently under discussion, but it can also be considered a minority position. This paper will not resolve these essential philosophical considerations, but will shed light on how these consensuses must be measured and, in particular, whether we can get to know community intuitions of justice.

\section{Punitive attitudes versus intuitions of justice: two dimensions of the relationship between public opinion and the penal system.}

When we raise the issue of public opinion with respect to the penal system, some arguments generally used by legislatures to criminalize a particular behaviour or increase sentences take the form of "social demand," "social outcry," etc. The tendency of legislatures in many countries to employ these social demands (Varona, 2008) has been defined and studied particularly in the international literature (Green, 2006; Hough \& Roberts, 1998; Maruna \& King, 2004; Roberts, Stalans, Indermaur, Hough, 2003; Roberts \& Hough, 2005; Allen, 2002; Roberts, 1992; Haines, 2007; Cullen, Skovron, Scott \& Button, 1990). Since the 1990s, multiple studies have examined citizens' attitudes towards the criminal justice system (Aizpurúa \& Fernández Molina, 2011; Aizpurúa, 2014; 2015) by attempting to analyse the hypothesis offered by Garland's (2001) theory of the "culture of control," or, more clearly, by the thesis of punitive populism introduced by Bottoms (1995, cited in Dzur, 2012). In Spain, authors such as Varona (2008), Aizpurúa and Fernández Molina (2011), Fernández 
Molina and Gómez Tarancón (2010), have carried out major studies whose main goal is to confirm, according to Anglo-Saxon literature, whether the "social demand" that legislators claim to justify revising the criminal code truly exists, and that evaluate social demands of the public with respect to the violation of norms (Fernández Molina \& Tarancón Gómez, 2010; Varona, 2008; 2009), as well as the effects of informed public opinion on their punitive demands (Aizpurúa \& Fernández Molina, 2011; Varona, 2016). These studies, then, cast doubt on the common beliefs that "the sentences are not harsh enough" (Doob, 2000) and make it particularly clear that politicians generally and systematically misinterpret society's demands from the penal system (Larrauri, 2005). In other words, this research focuses on evaluating public opinions about the functioning of the penal system and responds collaterally to the question of what the public wish to punish.

Other authors have analysed public opinions differently, not so much with respect to the global functioning of the criminal justice system already in place, but rather with respect to the very essence of the criminal justice system through the idea of intuitions of justice (Robinson \& Darley, 1995, Robinson, 2013). In fact, intuitions of justice are proposed as a way to approach people's idea of justice by conceptualizing it as the product of an intuitive knowledge as opposed to more complex reasoning processes, thereby extracting the factors that influence judgements about state punishment. According to this view, intuitions of justice are spontaneous judgements about the punishment that a person deserves for committing a crime (Robinson \& Darley, 2007), thus relating the notion of culpability to that of the just punishment. Furthermore, one of the main findings of the authors is a universal consensus on intuitions of justice (cross-cultural), or at least on a core of wrongdoing (Robinson \& Kurzban, 2007), to which they add that there are certain extremes of criminal law that are eminently intuitive, as that the sentence deserved for an attempt depends on how close the actor is to the completed crime, that for the accomplice it depends on the level of assistance provided to the principal actor, and that for the actor depends on whether he or she is in a position of guarantor or meets the necessary requirements for legitimate defence (Robinson \& Darley, 1995). 
What is truly interesting about Robinson and Darley's proposal, in any case, is that these intuitions can be useful for deriving rules for distribution of liability and punishment through lay intuitions of justice (Robinson \& Darley, 1995; Robinson, 2013). This notion is based on the idea that in regard to preventing crime, the power of interpersonal relationships and internalized norms is drastically superior to the power of public penalties (Robinson, 2012), so "laws based on community standards of deserved punishment enhance this obedience" (Robinson, 2012, p. 233). Empirical desert or legitimacy, which would be achieved when the subject perceives that the punishment is appropriate according to what he sees as just, constitutes - as has been demonstrated empirically in several experiments (Robinson, Barton, \& Lister, 2014; Robinson, 2012, 2013) and in quantitative studies in Spain (Bautista \& Miró Llinares, 2015; Bautista \& Sitges, 2016; Miró Llinares \& Bautista, 2013 ) - the essential distributive criterion for punishment modified by the constitutional demands of the social-democratic legal state. In other words, as we have stated elsewhere (Miró Llinares, 2017a), in the legal pronouncement phase, the function of punishment is to prevent the perpetration of injustice through general communication as the expressive confirmation of the social model of legitimate behaviour, which reinforces people's compliance as social subjects. This being the case, there is an obvious interest in confirming whether criminal law, by punishing completed homicide more harshly than for attempted homicide, is acting in accordance with a clear and defined social perception of different deserved punishments for each behaviour by the public.

The principal goal of this paper, then, is to analyse and evaluate whether, as indicated by the research of Robinson \& Darley (1995), there are shared and firm intuitions of justice about attempts and completed crimes. We will add, however, another goal that we find to be of interest, namely, to analyse whether these intuitions of justice are modified by specialized knowledge that people may have. In selecting their different samples, Robinson and his collaborators $(1995,2007,2010,2013)$ excluded people involved in the justice system: "judges, law students, or police officers, figuring that those people would have opinions that were to some extent formed by their contact with the system" (p. 8). This exclusion is interesting because if, as it confirms, intuitive knowledge is characterized precisely by being

Revista Española de Investigación Criminológica

Artículo 3, Número 17 (2019)

https://doi.org/10.46381/reic.v17i0.227

www.criminologia.net

ISSN: 1696-9219 
knowledge that is not based on concrete reasoning, and if having this kind of specialized knowledge could affect the intuitions of justice through which rules of criminal liability and distribution of punishment must be deduced, it would seem that the concept of intuition of justice is not as intuitive as it suggests and that the concept could be manipulated and influenced, with important repercussions.

\section{Objectives and hypotheses}

The general objective is to evaluate some intuitions of justice with respect to the crime of homicide in four different degrees: completed crime, completed attempt, incomplete attempt, and impossible attempt ${ }^{3}$. The crime chosen for this purpose corresponds to what Robinson \& Kurzban (2007) call the core of wrongdoing, referring to a category of crimes that include damage to person or damage to property by taking things without consent, such as deception in exchange. Both writers assert that "such wrongs are so central to effective group cooperation that they may arise in any group in any culture" (p. 1891).

To achieve this general objective, we propose the following specific objectives:

1. To determine the criminal liability and formal criminal punishment associated with each scenario.

2. To assess the perception of justice of formal punishments imposed by the Spanish Criminal Code.

3. To compare the different intuitions of justice across scenarios.

4. To analyse whether the study of law modifies intuitions of justice.

\footnotetext{
${ }^{3}$ The impossible attempt scenario does not correspond to the use attributed to that term in the continental theory of criminal law. By impossible attempt we understand a scenario in which there is no possibility of appreciating an attempt. With this case scenario not legally qualifiable as some kind of attempt according to our criminal law system, we wanted to test the maximum "cogitationes poenam nemo patitur". That is, we wanted to check whether the participants considered the intention of the subject despite not having any result and even in a case where the result was not possible.
}

Revista Española de Investigación Criminológica

Artículo 3, Número 17 (2019)

https://doi.org/10.46381/reic.v17i0.227

www.criminologia.net

ISSN: $1696-9219$ 
To achieve the specific objectives above, four hypotheses have been developed around the following intuitions of justice:

a) Judicial-criminal liability. It has been established that people are capable of perceiving differences among degrees of execution of a crime and accordingly grading judicial-criminal liability (Robinson \& Darley, 1995; Robinson 2000). Therefore, our corresponding hypothesis is that (H1) the participants will assign different judicial-criminal liability to the different scenarios.

b) Formal criminal sanction. The position of Robinson \& Darley (1995) is that people are capable of grading deserved punishment as a function of the differences among different scenarios. As a result, we hypothesize that (H2) the participants will assign a different criminal sanction to the different scenarios.

c) Perception of the justice of the Criminal Code. The studies that have considered whether society in fact demands greater punishment (Varona, 2008, Aizpurúa \& Fernández Molina, 2011) make clear that the public is not as punitive as legislators often assert when enacting penal reforms that generally increase sentences based on arguments about social demands. Thus, the hypothesis proposed here is twofold: (H3a) participants who assign the same criminal sanction as that of the Spanish Criminal Code will obtain higher scores on the perception of justice; and ( $\mathrm{H} 3 \mathrm{~b})$ participants who did not agree with the formal sanction in the Criminal Code will have chosen a less severe punishment.

d) Knowledge of the law. It is important to point out that whether one has knowledge of the law is obviously not an intuition of justice in and of itself, but rather an area of participants' expertise. In this context of specialized knowledge, the methodology followed by Robinson and his collaborators of removing such participants from their study samples leads us to suppose that the authors predict the following tendencies: (H4a) Participants who have studied law will distribute judicial-criminal liability differently from those who have not; and (H4b) 
participants who have studied law will distribute formal sanctions differently from those who have not.

\section{Methods}

\subsection{Participants}

The sample was composed of 659 participants who are residents of Spain, of whom $72 \%$ are women and $28 \%$ are men, with a median age of $29(\mathrm{SD}=10.51)$. In addition, $83 \%$ have a university education, and $30 \%$ of the total sample have studied law.

\subsection{Variables and instrument}

An ad hoc questionnaire was designed to measure the following dependent variables: (1) judicial-criminal liability, (2) formal sanction assigned by the participants to each scenario, and (3) perception of justice in relation to the real formal sanction established in the Criminal Code. With respect to the independent variables, on the one hand, we have the different scenarios (i.e., a completed act, a completed attempt, an incomplete attempt, and an impossible attempt; see description in Annex I), and on the other hand, we have the pseudomanipulation of our quasi-experimental design with knowledge about the law that creates the experimental conditions (see design type). As a result, we have determined that the most appropriate way to evaluate intuitions of justice is by using scenarios (León \& Aizpurua, 2017; Pozuelo Pérez, 2013), which is an ideal technique when "participants may be unable to explicitly weight and integrate the elements involved in complex decisions" (Carlsmith, Darley \& Robinson, 2002, p. 287). In keeping with this last point, we have presented subjects with scenarios to judge and thereby infer the principles of these judgements based on the response patterns in the different cases (Robinson, 2000).

With respect to the dependent variables, we used the following items: 
1. Judicial-criminal liability: To what degree do you believe that "A"'s conduct should be judged by the law? Participants were asked to respond on a scale of 0 to 10 , where 0 means that "I think the conduct should not be judged by the law in no case" and 10 means that "I believe that the conduct should be judged by the law in every case."

2. Deserving of formal sanction: What formal sanction do you believe "A" would deserve given the facts provided? In this case, participants were provided with 13 possible punishments ${ }^{4}$ ranging from no punishment to the death penalty and graded them from lesser to greater according to how they would affect individual liberty. 3. Perception of justice of the Criminal Code's penalty. Taking as an example the scenario of a completed crime: The crime of homicide is punished in our Criminal Code by a prison sentence of 10 to 15 years. How do you evaluate this sanction? With respect to the rest of the scenarios, an impossible attempt has no formal sanction associated with it, whereas an incomplete attempt is punished by a prison sentence of $2 \frac{1}{2}$ to 5 years, and a completed attempt by a prison sentence of 5 to 10 years. A scale of 0 to 10 was provided for the response, where 0 means "totally unjust" and 10 means "totally just."

Finally, participants' knowledge of the law was assessed with a dichotomous item: Have you studied law?

\subsection{Procedure}

The survey was distributed through paid advertising services on Facebook. We used Google's free survey system to develop the survey. The eligibility criteria for participating in the study were as follows: 1) being a Facebook user living in Spain; 2) being at least 13 years old; and

\footnotetext{
${ }^{4}$ Specifically, the response choices were as follows: No punishment; monetary fine; community service; probation; 3 months to one year in prison; more than one year to 5 years in prison; more than 5 years to 10 years in prison; more than 10 years to 15 years in prison; more than 15 years to 20 years in prison; more than 20 years to 25 years in prison; more than 25 years to 30 years in prison; life in prison with the possibility of parole; and the death penalty.
}

Revista Española de Investigación Criminológica

Artículo 3, Número 17 (2019)

https://doi.org/10.46381/reic.v17i0.227

www.criminologia.net

ISSN: 1696-9219 
3) speaking Spanish. The campaign was developed over a week, with a potential reach of $21,000,000$ people but obtaining a total of 659 valid responses. In addition, a link was programmed to randomly distribute the four questionnaires corresponding to the four scenarios.

\section{Table 1.}

Distribution of the sample for each scenario

\begin{tabular}{|l|r|r|r|r|r|}
\hline \multirow{2}{*}{\multicolumn{1}{|c|}{ Scenario }} & \multirow{2}{*}{ N (\%) } & \multicolumn{2}{|c|}{ Sex } & \multirow{2}{*}{ Meanage (DT) } & $\begin{array}{c}\text { Studies in law } \\
\text { (\%) }\end{array}$ \\
\cline { 3 - 4 } & & Women (\%) & Men (\%) & & \\
\hline Impossible attempt & $166(25.2)$ & $123(74.1)$ & $43(25.9)$ & $28.73(9.58)$ & $52(31.3)$ \\
Incomplete attempt & $161(24.4)$ & $115(71.4)$ & $46(28.6)$ & $29.27(11.16)$ & $52(32.3)$ \\
Completed attempt & $155(23.5)$ & $110(71.0)$ & $45(29.0)$ & $30.15(10.90)$ & $44(28.4)$ \\
Completed crime & $177(26.9)$ & $126(71.2)$ & $51(28.8)$ & $29.14(10.42)$ & $50(28.2)$ \\
\hline
\end{tabular}

\subsection{Design type}

This study incorporates a double design. First, an exploratory non-experimental design characterized by scenarios corresponding to the crime of homicide in four different degrees was aimed at evaluating hypotheses $\mathrm{H} 1, \mathrm{H} 2, \mathrm{H} 3 \mathrm{a}$ and $\mathrm{H} 3 \mathrm{~b}$. In addition, given the important subsample made up of participants who have studied law (see Participants), a second study was designed based on the artificial creation of two experimental conditions that allowed us to respond to hypotheses $\mathrm{H} 4 \mathrm{a}$ and $\mathrm{H} 4 \mathrm{~b}$ : participants who have not studied law (control group) and participants who have studied law (experimental group). 


\section{Results}

\subsection{H1. Regarding judicial-criminal liability}

The first proposed hypothesis is that the participants will assign different judicial-criminal liability to the different scenarios. In this case, having to compare more than four groups, we conducted the contrasts based on variances rather than medians. Because the assumption of homoskedasticity is violated $(F=7.754 ; p=.000)$, the comparison among groups was conducted using the Kruskal-Wallis test.

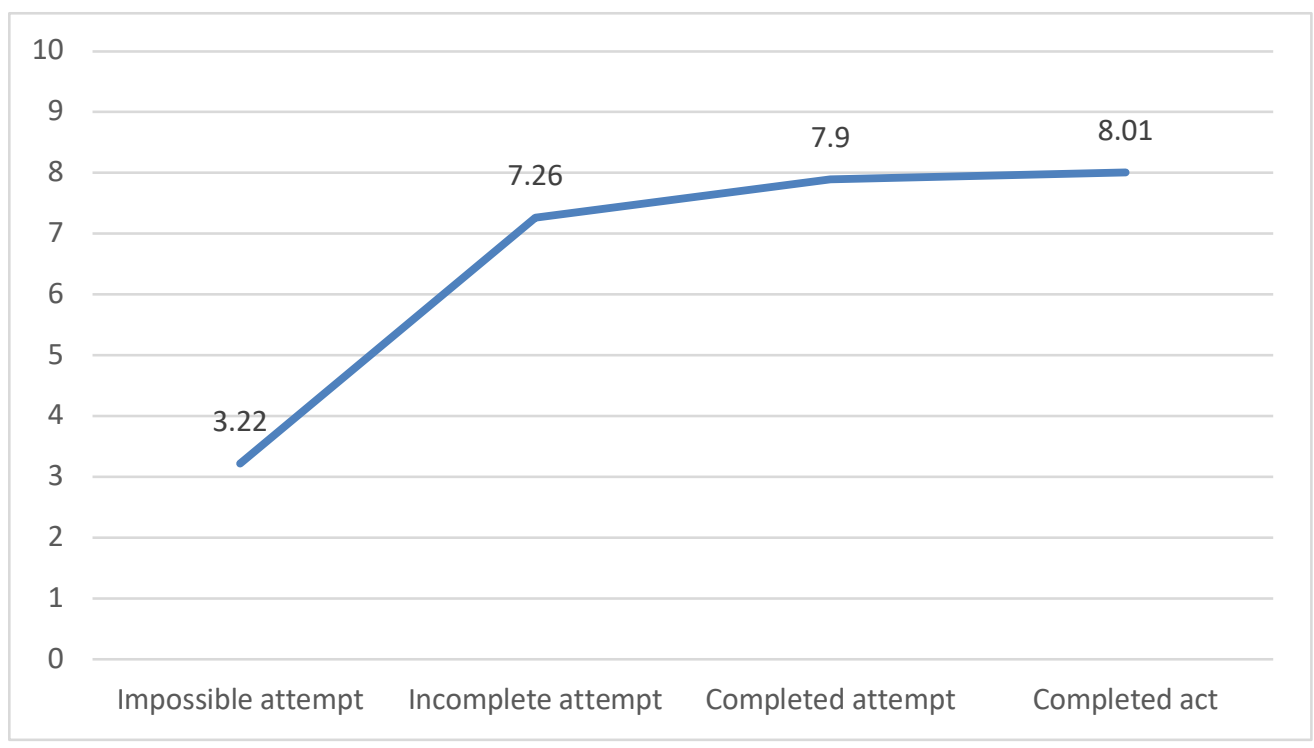

Figure 1: Means of "judicial-criminal liability" for each scenario. 


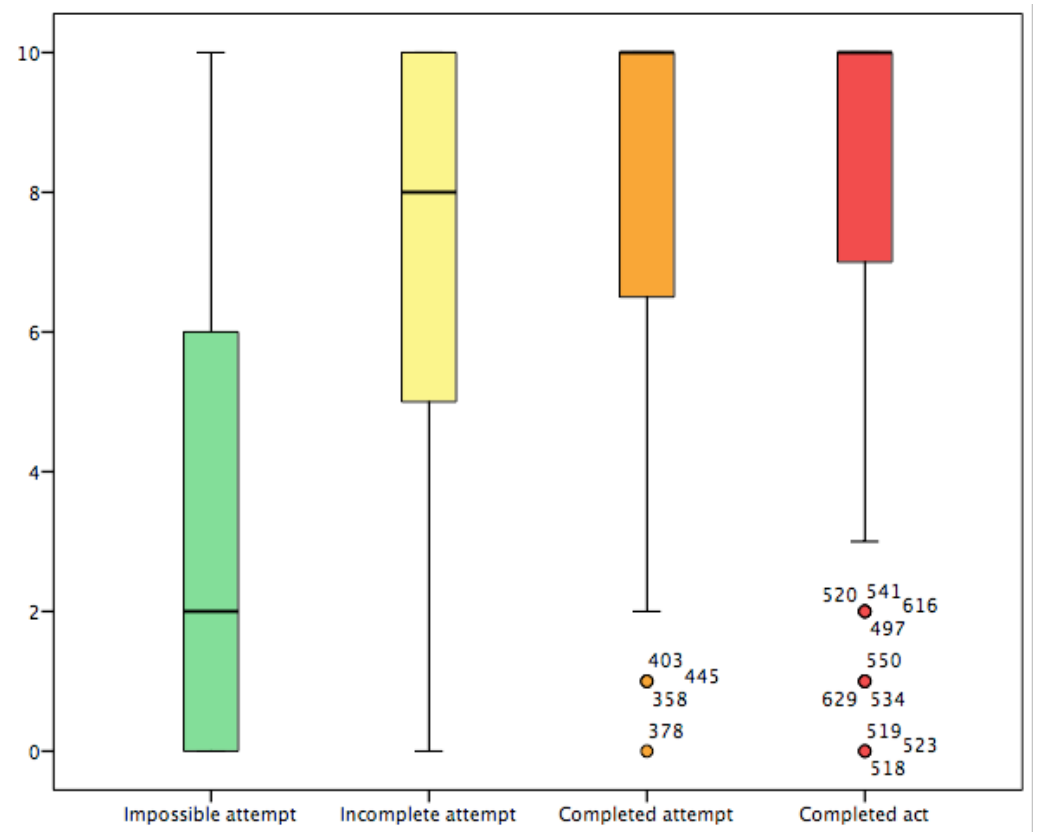

Figure 2: Box plot diagram (Judicial-criminal liability).

As shown in Figure 1, the participants assign an increasing median judicial-criminal liability to each scenario. This difference was shown to be statistically significant by applying the corresponding statistic $\left(\chi^{2}=173.403 ; p=.000\right)$. The difference is statistically significant in a general way, but it does not provide us with enough information on each specific case. For that reason, Table 2 shows the Kruskal-Wallis analyses in pairs:

Table 2.

Contrasts for judicial-criminal liability by pairs of scenarios

\begin{tabular}{lccc}
\hline Scenario* & $\boldsymbol{\chi}^{\mathbf{2}}$ & $\boldsymbol{E S}$ & $\boldsymbol{P}$ \\
\hline IA - InA & 187.474 & 20.367 & .000 \\
IA - CA & -224.802 & 20.566 & .000 \\
IA - C & -229.575 & 19.894 & .000 \\
InA - CA & -37.328 & 20.719 & .430 \\
InA - C & -42.101 & 20.053 & .215 \\
CA - C & -4.773 & 20.255 & 1.000 \\
\hline *Impossible attempt (IA), Incomplete attempt (InA), Completed attempt (CA), Completed act (C).
\end{tabular}


The differences shown in Table 2 are not among all the pairs but only between impossible attempt and the other scenarios. The statistics show that in terms of judicialcriminal liability, there are not statistically significant differences with respect to the other assumptions. In accordance with these results, we can accept H1, but only partially.

\subsection{H2 regarding deserved formal sanction}

The second hypothesis is that the participants will assign a different formal sanction to the different scenarios. As predicted during the study design process, the variability of the responses was fairly wide, as participants were provided with a list of 13 possible judicialcriminal consequences so that they could be as specific as possible in their responses and knew what level of formal sanction they were assigning to each case. Table 3 shows the response options chosen by the majority by the participants (i.e. mode) regarding the sanctions provided for each case scenario.

\section{Table 3.}

Mode of the formal sanctions for each scenario

\begin{tabular}{llc}
\hline \multicolumn{1}{c}{ Scenario } & \multicolumn{1}{c}{ Mode } & $\%$ \\
\hline Completed crime & Prison for more than 10 years to 15 years & $20.9 \%$ \\
Completed attempt & Prison for more than 1 year to 5 years & $30.3 \%$ \\
Incomplete attempt & Prison for more than 1 year to 5 years & $31.1 \%$ \\
Impossible attempt & No punishment & $43.4 \%$ \\
\hline
\end{tabular}

As with H1, when we compared more than two heteroskedastic samples $(F=6.105$; $p=.000$ ), we used the contrast statistic of the Kruskal-Wallis test. The results show that there are statistically significant differences in terms of deserved punishment in a general sense between the different scenarios $\left(\chi^{2}=234.09 ; p=.000\right)$. In contrast to the pair comparison and unlike the previous hypothesis, the differences are statistically significant in every case (see Table 4), which allows us to accept $\mathrm{H} 2$. 
Table 4.

Contrasts for formal sanctions by pairs of scenarios

\begin{tabular}{lccc}
\hline \multicolumn{1}{c}{ Scenarios* } & $\boldsymbol{\chi}^{\mathbf{2}}$ & $\boldsymbol{E S}$ & $\boldsymbol{p}$ \\
\hline IA - InA & -162.840 & 20.894 & .000 \\
IA - CA & -222.399 & 21.099 & .000 \\
IA - C & -302.97 & 20.409 & .000 \\
InA - CA & -59.560 & 21.256 & .030 \\
InA - C & -140.130 & 20.572 & .000 \\
CA - C & -80571 & 20.780 & .001 \\
\hline
\end{tabular}

*Impossible attempt (IA), Incomplete attempt (InA), Completed attempt (CA), Completed act (C)

\subsection{H3a and $\mathrm{H} 3 \mathrm{~b}$ regarding perception of justice}

Regarding the perception of the justice of the sanction imposed by the Criminal Code, we put forward two different, but closely related, hypotheses. First, according to H3a participants who assign the same criminal sanction as the Criminal Code will obtain higher scores on the perception of justice.

\section{Table 5.}

Description of the concordance between the sanction imposed by the participants and the sanction imposed by the Criminal Code

\begin{tabular}{lcccc}
\hline Concordance & N & \% & Mean & SD \\
\hline No & 465 & $70.5 \%$ & 4.99 & 3.232 \\
Yes & 194 & $29.5 \%$ & 7.43 & 2.905 \\
\hline
\end{tabular}

As Table 5 shows, participants who did not agree with the sanction imposed by the Criminal Code obtained, on average, a lower score on that variable. Additionally, in agreement with the contrast test, the differences are statistically significant $(t=-9.372$; $p=.000)$, which allows us to accept H3a.

According to $\mathrm{H} 3 \mathrm{~b}$ participants who did not agree with the formal sanction in the Criminal Code will have chosen a less severe sanction. To confirm this hypothesis, we evaluated formal sanctions corresponding to the 465 participants who did not agree with the actual punishment in the Criminal Code. Table 6 shows that except in the case of an

Revista Española de Investigación Criminológica

Artículo 3, Número 17 (2019)

https://doi.org/10.46381/reic.v17i0.227

www.criminologia.net

ISSN: 1696-9219 
impossible attempt, all other scenarios were assigned a lower penalty than the one imposed by the Criminal Code, with this difference more pronounced for the completed and incomplete attempt than for the completed crime. Although the chi-square test shows general statistically significant differences $\left(\chi^{2}=136.286 ; p=.000\right)$, it would be prudent to partially accept $\mathrm{H} 3 \mathrm{~b}$ and suspend judgement on the case of completed crime pending further data.

\section{Table 6.}

Distribution of the punitiveness of sanctions for participants who did not agree with the actual formal sanction in the Spanish Criminal Code

\begin{tabular}{lcccc}
\hline & $\begin{array}{r}\text { Completed } \\
\text { crime }\end{array}$ & $\begin{array}{r}\text { Completed } \\
\text { attempt }\end{array}$ & $\begin{array}{r}\text { Incomplete } \\
\text { attempt }\end{array}$ & $\begin{array}{r}\text { Impossible } \\
\text { attempt }\end{array}$ \\
\hline $\begin{array}{l}\text { Greater } \\
\text { punitiveness }\end{array}$ & $42.1 \%$ & $25.4 \%$ & $34.9 \%$ & $100 \%$ \\
$\begin{array}{l}\text { Lesser } \\
\text { punitiveness }\end{array}$ & $57.9 \%$ & $74.6 \%$ & $65.1 \%$ & $0 \%$ \\
\hline
\end{tabular}

\subsection{H4a and H4b regarding knowledge of the law}

Finally, in line with the observation made earlier on the methodology of Robinson and his collaborators regarding the exclusion of participants with specialized knowledge of the law from samples (Robinson \& Darley, 1995), we have presented two final hypotheses that may allow us to understand whether such exclusion is sufficiently justified. First, H4a predicted that participants who have studied law will distribute judicial-criminal liability differently from those who have not. 


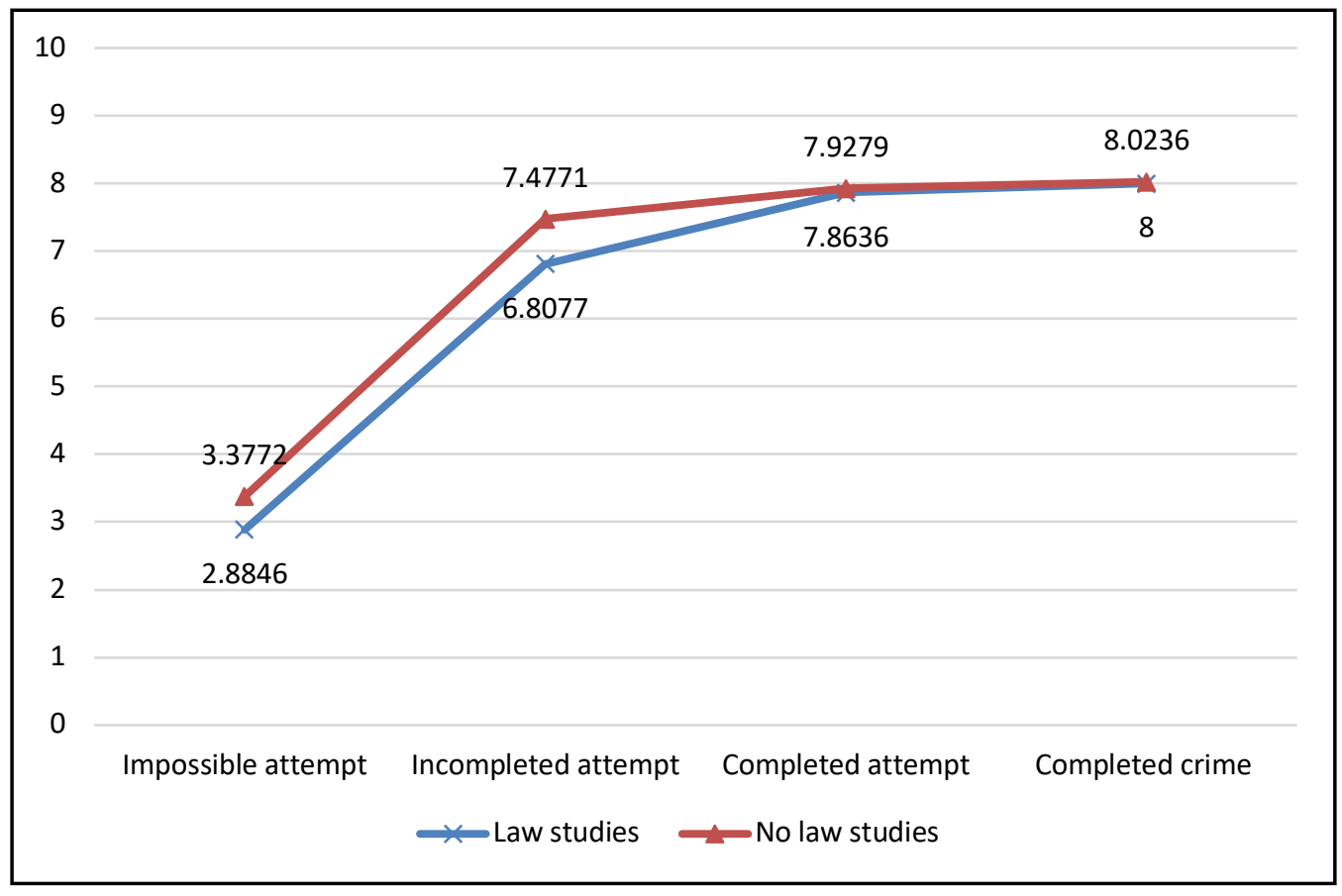

Figure 3: Comparison of "judicial-criminal liability": group who has studied law/group who has not studied law.

As shown in Figure 3, from a descriptive perspective, we can detect certain differences in the medians, especially for incomplete attempt; nevertheless, in the case of completed attempt and completed crime, both points nearly coincide. Given the heteroskedasticity of the data, we developed contrast analyses using the nonparametric Mann-Whitney $U$ test, which yielded the following results for each scenario: impossible attempt $(z=-1.107 ; p=.268)$, incomplete attempt $(z=-1.04 ; p=0.299)$, completed attempt $(z=$ $-0.103 ; p=.918)$ and completed crime $(z=-0.392 ; p=.694)$. As a result, we cannot reject the null hypothesis for $\mathrm{H} 4 \mathrm{a}$. 


\section{Discussion}

The results of our study show how participants attributed different levels of judicial-criminal liability (see Table 2) and formal punishment (see Table 4) to various scenarios. These results are consistent with Cushman (2008) that in cases involving punishment and blame, individuals who attempt a crime but fail to cause harm are judged more leniently than those who completed the crime and inflicted harm. Similarly, Darley, Sanderson and LaMantia (1996) concluded that for both homicide and robbery, participants assigned greater liability to a subject who came closer to actual completion of the crime. It seems quite significant to us that, even when dealing with different scenarios, we find a majority assessment that an attempt to kill is not as serious as killing. The Criminal Code's assignment of different levels of punishment to attempted and completed crimes would therefore correspond to a clear societal intuition of justice. This, in turn, as we have said, would indicate that as long as the hypotheses confirmed by empirical studies about the influence of legitimacy on compliance with norms endure (see Miró Llinares, 2017b; Robinson 2010, 2012, 2013), then a potential preventive effect that implies that the behavioural model determined by the law should correspond to moral intuitions themselves would be appropriate, more so than if the punishment for a completed crime was the same as that for an attempted crime.

On the other hand, in relation to the perception of the justice of the sanctions imposed by the Criminal Code, it has been shown how those who scored less on this variable assigned a less severe penalty to the scenario evaluated. We may suggest that this result is an indication of our participants' attitudes towards punishment, which could be categorized as less punitive, in line with several of the most relevant national studies (Varona, 2008; Aizpurúa \& Fernández Molina, 2011).

One of the most revealing findings of this study may be that, in contrast to what was initially hypothesized based on the research of Robinson and his collaborators (Robinson \& Darley, 1995), individuals who have studied law distributed liability and punishment in the same way as those who have no specialized knowledge. It seems to us that this reinforces the validity of intuitions of justice by confirming that intuitive knowledge about what is right

Revista Española de Investigación Criminológica

Artículo 3, Número 17 (2019)

https://doi.org/10.46381/reic.v17i0.227

www.criminologia.net

ISSN: 1696-9219 
and what is wrong does not depend on specialized knowledge. In this sense, our results suggest that it is not necessary to exclude people who have studied law from samples of studies concerning citizens' intuitions of justice, as Robinson (1995) does, at least with respect to testing such institutions of criminal law as the degree of execution of the crime of homicide, although this may need to be confirmed for other types of crimes.

Along with these other interesting results, we believe that there is another finding that should not be dismissed: we have demonstrated that we can empirically examine an issue that has been widely discussed in theory. We are well aware of the limitations of the study and that these must be considered when interpreting the results: the problems inherent in the sample's lack of representativeness, the brevity of the instrument, the operationalization of the first item (i.e., judicial-criminal liability) and the seriousness of the crime considered (Aizpurúa \& Fernández-Molina, 2016). Nevertheless, with the different possibilities offered by empirical methodologies and their designs, a study such as this is an example of how jurists can open the doors to the empirical falsification processes to scientifically determine how to study society in an empirically valid and not merely axiological or speculative manner (Miró Llinares, 2018). 


\section{References}

Aizpurúa González y Fernández Molina (2011). Información, ¿antídoto frente al "populismo punitivo"?. Estudio sobre las actitudes hacia el castigo de los menores infractores y el sistema de Justicia Juvenil. Revista Española de Investigación Criminológica, (9), ISSN: 1696-9219

Aizpurúa González, E. (2014). Presente y future del studio de la opinión pública hacia el castigo de los menores infractores. Evidencias, carencias y posibilidades. Revista Española de Investigación Criminológica, 12. Recuperado a partir de https://reic.criminologia.net/index.php/journal/article/view/81.

Aizpurúa González, E. (2015). Delimitando el punitivismo. Las actitudes de los españoles hacia el castigo de los infractores juveniles y adultos. Revista Española de Investigación Criminológica, 13. Recuperado a partir de https://reic.criminologia.net/index.php/journal/article/view/90.

Aizpurúa, E., \& Fernández-Molina, E. (2016). Opinión pública hacia el castigo de los delincuentes: La importancia del delito cometido. Boletín Criminológico, 1(161), ISSN: 2254-2043

Allen, R. (2002). What Does the Public Think about Prison? Criminal Justice Matters, 49, DOI: $10.1080 / 09627250208553484$.

Bautista Ortuño, R., \& Sitges Maciá, E. (2016). Análisis de los predictores psicosociales de la transgresión de normas de tráfico en España: los casos del uso del cinturón, del teléfono móvil, los límites de velocidad y el límite de alcoholemia al volante. Revista Española de Investigación Criminológica, (14), ISSN: 1696-9219.

Bautista Ortuño, R., y Miró Llinares, F. (2015). ¿Por qué algunos siempre incumplen?: Infractores y multi-infractores en seguridad vial. Indret: Revista para el Análisis del Derecho, (4), ISSN: 1698-739X.

Bittner, T (2008). Punishment for Criminal Attempts: A Legal Perspective on the Problem of Moral Luck. Canadian Journal of Philosophy, 38(1), DOI: 10.1353/cjp.0.0010.

Christopher, R. (2004). Does Attempted Murder Deserve Greater Punishment than MurderMoral Luck and the Duty to Prevent Harm. Notre Dame Journal of Law, Ethics \& Public Policy, vol. 18, Issue 2, Article 11, pp. 419-435. Disponible en: https://scholarship.law.nd.edu/ndjlepp/vol18/iss2/11

Cullen, F. T., Skovron, S. E., Scott, J. E., \& Burton, V. S. (1990): Public support for correctional treatment. The tenacity of rehabilitative ideology. Criminal Justice and Behavior, 17(1), DOI: 10.1177/0093854890017001003.

Cushman, F. (2008). Crime and punishment: Distinguishing the roles of causal and intentional analyses in moral judgment. Cognition, 108(2), DOI: 10.1016/j.cognition.2008.03.006.

Revista Española de Investigación Criminológica

Artículo 3, Número 17 (2019)

https://doi.org/10.46381/reic.v17i0.227

www.criminologia.net

ISSN: 1696-9219 
Darley, J. M., Sanderson, C. A. \& LaMantia, P. S. (1996). Community Standards for Defining Attempt. Inconsistencies with the Modal Penal Code. American Behavioral Scientist, 39(4), DOI: $10.1177 / 0002764296039004005$.

Deeley, K. (2016). Punishing Criminal Attempts: The Role of Harm in Criminal Sentencing. Padeia, 3 (1), 17.

Donnelly-Lazarov, B. (2015). A Philosophy of Criminal Attempts. Cambridge University Press.

Doob, A. N. (2000). Transforming the punishment environment: Understanding public views of what should be accomplished at sentencing. Canadian Journal of Criminology and Criminal Justice, 42(3).

Duus Otterström, G. (2018). Retributivism and Public Opinion: On the Context Sensitivity of Desert. Crim Law and Philos, 12, pp. 125-142, DOI: 10.1007/s11572-017-9415-z.

Dzur, A. W. (2012). Participatory Democracy, \& the Jury. Oxford University Press.

Feinberg, J. (1995). Equal punishment for failed attempts: Some bad but instructive arguments against it. Arizona Law Review., 37, 117.

Fernández Molina, E y Tarancón Gómez (2010). Populismo punitivo y delincuencia juvenil: mito o realidad. Revista Electrónica de Ciencia Penal y Criminología, RECPC 1208, ISSN 1695-0194.

Fletcher, G. P. (2000). Rethinking Criminal Law. Oxford: Oxford University Press.

Garland, D. (2001). The culture of control. Oxford: Oxford University Press.

Gil Gil, A. (2015). Lección 13. Iter criminis. En Gil Gil, A., Lacruz López, J. M., Melendo Pardos, M., y Núñez Fernández, J. (2015). Curso de Derecho Penal. Parte General ( $2^{\mathrm{a}}$ edición). Dykinson, Madrid.

Green, D. A. (2006). Public opinion versus public judgment about crime: Correcting the “comedy of errors". British Journal of Criminology, 46(1), DOI: 10.1093/bjc/azi050.

Habermas, J. (2001). Teoría de la acción comunicativa, I. Racionalidad de la acción y racionalización social. Taurus Humanidades

Haines, A. (2007). Juvenile crime and punishment in Bucharest, Romania: A public opinion survey. Internet Journal of Criminology. Disponible en: https://goo.gl/6dDiTX

Hough, M. \& Roberts, J. V. (1998). Attitudes to punishment: Findings from the British Crime Survey. London: Home Office.

Larrauri, E. (2005). Populismo punitivo... y cómo resistirlo. Jueces para la democracia (55), ISSN: 1133-0627.

León, C. M., \& Aizpurua, E. (2017). ¿Formulación abierta o cerrada de las preguntas en los cuestionarios? Resultados de un experimento sobre opinión acerca de la finalidad de las penas. Boletín Criminológico, (174), ISSN: 2254-2043.

Lippke, R. L. (2016). Harm Matters: Punishing Failed Attempts. Ohio State Journal of Criminal Law, 14, pp. 629-646.

Revista Española de Investigación Criminológica

Artículo 3, Número 17 (2019)

https://doi.org/10.46381/reic.v17i0.227

www.criminologia.net

ISSN: 1696-9219 
Mañalich Raffo, J. P. (2004). La tentativa y el desistimiento en el Derecho Penal. Algunas consideraciones conceptuales. Revista de Estudios de la Justicia, (4), ISSN: 01180853.

Maruna, S. \& King, A. (2004). Public opinion and community penalties. En T. Bottoms, S. Rex \& G. Robinson (Eds.), Alternatives to prison: Options for an insecure society. Cullompton: Willan.

Mir Puig, S. (2015). Derecho penal. Parte General (10ª edición). Barcelona: Reppertor.

Miró Llinares, F. (2017a). La función de la pena ante "el paso empírico" del derecho penal. Revista General de Derecho Penal, (27), ISSN: 1698-1189.

Miró Llinares, F. (2017b). Aproximación a la función de la pena desde evidencias sobre el cumplimiento normativo. En Silva Sánchez, J. Mª/Queralt Jiménez, J. J./Corcoy Bidasolo, M./Castiñeira Palou, Ma . T. (Coords.): Estudios de Derecho Penal. Homenaje al profesor Santiago Mir Puig. Buenos Aires: BdeF.

Miró Llinares, F. (2018). Hechos en tierra de normas. Una introducción epistemológica a la relevancia de la realidad fáctica en el Derecho penal. En Suárez Jópez, J. M./Barquín Sanz, J./Benítez Ortúzar, I. F./Jiménez Díaz, M. J./ Sainz-Cantero Caparrós, J. E. (Dirs.). Estudios Jurídicos Penales y Criminológicos. En Homenaje al Prof. Dr. Dr. H. C. Mult. Lorenzo Morillas Cueva, Dikinson, Madrid, 2018

Miró Llinares, F., \& Bautista Ortuño, R. (2013). ¿Por qué cumplimos las normas penales?: Sobre la disuasión en materia de seguridad vial. Indret: Revista para el Análisis del Derecho, (4), ISSN: 1698-739X.

Morris, N. (1974). The future of imprisonment. Chicago: University of Chicago Press.

Nino, C. S. (1988). Constructivismo epistemológico: entre Rawls y Habermas. Recuperado de: https://rua.ua.es/dspace/bitstream/10045/10869/1/Doxa5 05.pdf

Pozuelo Pérez, L. (2013). La política criminal mediática. Génesis, desarrollo y costes. Madrid: Marcial Pons.

Roberts, J. V. (1992). Public opinion, crime and criminal justice. Crime and Justice: A review of research, 16, DOI: 10.1086/449205.

Roberts, J. V., \& Hough, M. (2005). Understanding public attitudes to criminal justice, New York/Maidenhead: Open University Press.

Roberts, J. V., Stalans, L. J., Indermaur, D. \& Hough, M. (2003). Penal populism and public opinion. Lessons from five countries. New York: Oxford University Press.

Robinson (2013b). Intuitions of Justice and the Utility of Desert. New York: Oxford University Press.

Robinson, P. H. \& Kurzban, R. O. (2007). Concordance \& Conflict in Intuitions of Justice. Faculty $\quad$ Scholarship, $122 . \quad$ Disponible en: https://scholarship.law.upenn.edu/faculty_scholarship/122/.

Revista Española de Investigación Criminológica

Artículo 3, Número 17 (2019)

https://doi.org/10.46381/reic.v17i0.227

www.criminologia.net

ISSN: 1696-9219 
Robinson, P. H. (2000). Testing Lay Intuitions of Justice: How and Why? Hofstra Law Review, 28, DOI: 10.2139/ssrn.381420.

Robinson, P. H. (2012). Principios distributivos del Derecho penal. A quién debe sancionarse y en qué medida. Madrid: Marcial Pons.

Robinson, P. H. (2013a). El papel que corresponde a la comunidad en la determinación de la responsabilidad penal y de la pena (Traducido por Vicente Valiente Iváñez). Perspectiva Penal Actual, (2).

Robinson, P. H., \& Darley, J. M. (2007). Intuitions of justice: Implications for criminal law and justice policy. California Law Review, 81.

Robinson, P. H., Barton, J. S., \& Lister, M. (2014). Empirical Desert, Individual Prevention, and Limiting Retributivism. New Criminal Law Review: In International and Interdisciplinary Journal, 17(2).

Robinson, P. H., Goodwin, G. P., \& Reisig, M. D. (2010). The disutility of injustice. New York University Law Review, 85, 1940.

Ronbinson \& Darley (1995). Justice, Liability, and Blame. Community Views and the Criminal Law. Boulder: Westview Press.

Roxin, C. (2014). Derecho penal. Parte General. Tomo II. Especiales formas de aparición del delito. Madrid: Civitas.

Roxin, C. (2017). El fundamento del castigo de la tentativa idónea e inidónea. En Silva Sánchez, J. M., Queralt Jiménez, J. J., Corcoy Bidasolo, M., Castiñeira Palou, M. T. (2017). Estudios de derecho penal: homenaje al profesor Santiago Mir Puig.

Serrano Piedecasas, J. R. (1999). Fundamento de la Punición de la Tentativa. Nuevo Foro Penal, (61).

Varona Gómez, D. (2008). Ciudadanos y actitudes punitivas: un estudio piloto de la población universitaria española. Revista Española de Investigación Criminológica, 6. Recuperado a partir de https://reic.criminologia.net/index.php/journal/article/view/40.

Varona Gómez, D. (2009). ¿Somos los españoles punitivos? Actitudes punitivas y reforma penal en España. Indret, 1/2009, ISSN-e 1698-739X.

Varona Gómez, D. (2016). El debate ciudadano sobre la justicia penal y el castigo: razón y emoción en el camino hacia un Derecho penal democrático. Marcial Pons: Madrid.

Revista Española de Investigación Criminológica

Artículo 3, Número 17 (2019)

https://doi.org/10.46381/reic.v17i0.227

www.criminologia.net

ISSN: 1696-9219 


\section{Acknowledgement}

We would like to thank Fco. Javier Castro Toledo for his help designing the study and providing feedback on the methodology.

\section{Funding}

This article was developed within the framework of research Project DER2017-86204-R, "Criminology, evidence and criminal policy: On the incorporation of scientific data into decisions about criminalization of behaviour", funded by the Spanish ministry of Economy, Industry and Competitiveness.

Ana Belén Gómez Bellvís is a full-time researcher at the CRÍMINA Center for the Study and Prevention of Crime.

Fernando Miró Llinares is Professor of Criminal Law and Criminology at the Miguel Hernández University of Elche, Dean of the Faculty of Social and Juridical Sciences of Elche, and Director of the CRÍMINA Center for the Study and Prevention of Crime at the Miguel Hernández University.

iD https://orcid.org/0000-0001-6379-5857

Artículo 3, Número 17 (2019)

https://doi.org/10.46381/reic.v17i0.227

www.criminologia.net

ISSN: 1696-9219 


\section{ANNEX I}

\section{Completed act scenario}

"A" decided to kill "B." With this idea, he got up in the morning, took out the pistol that he kept in his nightstand, and went to "B"'s workplace. He waited until the end of "B"'s workday, and from the sidewalk in front, he took out the gun, pointed it at "B," and shot. The bullet hit "B" in the head, and he died.

\section{Completed attempt scenario}

"A" decided to kill "B." With this idea, he got up in the morning, took out the pistol that he kept in his nightstand, and went to "B"'s workplace. He waited until the end of "B"'s workday, and from the sidewalk in front, he took out the gun, pointed it at "B," and shot. However, because of the noise of the shot, "B" jerked his head, which saved his life. The bullet hit the wall five centimetres from his head. While "A" was aiming again, he was arrested by the police.

\section{Incomplete attempt scenario}

"A" decided to kill "B." With this idea, he got up in the morning, took out the pistol that he kept in his nightstand, and went to "B"'s workplace. He waited until the end of "B"'s workday, and when he saw him in the doorway, he began to shoot, but the pistol was unloaded. Then, he quickly looked in his pocket for bullets, and as he was about to put them in the pistol, he was arrested by the police.

\section{Impossible attempt scenario}

"A" decided to kill "B". With this idea, he got up in the morning, took out the pistol that he kept in his nightstand, and went to "B"'s workplace. He waited until the end of "B"'s workday. From the sidewalk in front, he saw through the window that " $\mathrm{B}$ " walked out of the building's elevator and suddenly collapsed on the floor. "B" had suffered a heart attack and died immediately. After observing the scene, "A" went home.

\section{Revista Española de Investigación Criminológica}

Artículo 3, Número 17 (2019)

https://doi.org/10.46381/reic.v17i0.227

www.criminologia.net

ISSN: 1696-9219 